mena which, although apparently simple, cannot be explained psychologically from a single cause but are due to several factors. Franz Boas.

\section{RECENT HYDROGRAPHIC EXAMINATIONS IN} THE APPALACHIAN AREA.*

THE systematic study of the discharges of the streams of the United States has, with one or two exceptions, been undertaken only in recent years. The expense and time required for such investigations prohibits the private engineer from undertaking them, and they can be carried on, therefore, only by large corporations, municipal or State authorities, or by the National Government. Among the most valuable contributions to this branch of engineering have been investigations ordered by the cities of Boston and New York in connection with the study of their water supply. The Sudbury records for Boston supply data since 1875 and those of the Croton for New York since 1868. These are on relatively small basins, however, the former having a drainage area of 78 square miles and the latter 353 square miles.

The army engineers in connection with the improvement of the Connecticut river carried on systematic observations of the discharge of that river at Hartford, Conn., from 1871 to 1879 , inclusive, and from that period to the present time the Holyoke Water Power Company have continued the observations. The company in charge of the water powers at Lowell and Lawrence, Mass., on the Merrimac river, have carried on measurements of discharges for over fifty years, but their engineers have published little information. The State of New Jersey, in the interest of her water powers, and the city of Philadelphia, for the future de-

\footnotetext{
* Read before the National Geographic Society, November 15,1895 , by F. H. Newell, U. S. Geological Survey, Washington, D. C.
}

velopment of her water supply, commenced seven and nine years ago, respectively, the study of certain drainage basins, but they are also relatively small areas. The U.S. Geological Survey, in May, 1891, established a gauging station on the Potomac at Chain Bridge, D. C., for the measurement of the discharge of the river at that place. It was started somewhat as an experimental station, the time given to it being that which could be spared by hydrographers from office work. Gauge height observations were continued until the end of 1893 , when, on account of lack of time and of funds, they were discontined.

It has for years been the desire of the hydrographers of this survey to make a thorough and detailed study of the drainage system of one large river, to measure its different tributaries, and to study the relation of their discharges to that of the entire system. An opportunity was afforded for the development of this plan in the spring of 1894, and the Potomac basin was chosen as being convenient of access and as typical of large areas along Appalachian range. Gauging stations were established as follows: First, on the North Branch at Cumberland, Md.; second, on the South Branch three miles above Springfield, W. Va. ; third, at Dam No. 6, ten miles above Hancock, Md. ; fourth, one on the Shenandoah at Millville, W. Va., five miles above its mouth, and fifth, one on the main river at Point of Rocks, Md. Daily observations of the height of the river at Chain Bridge were also resumed, but measurements of the discharge were not made, as it was found that this point was not a favorable location for such measurements. In high water the velocity is too great, owing to the restricted channel, and in low water the daily tides introduce errors that are hard to eliminate. Work was actively prosecuted in this basin during the past spring, and a sufficient number of gaugings were made to construct 
rating curves for each station, by means of which the daily discharge can be computed.

In July, 1895, it was decided to expand the work of stream measurements in the South. Before doing so many factors entering into the location of gauging stations had to be considered. To more clearly understand the reasons of the location of the stations established during 1895 , it may be well to give a brief summary of the physical geography of the area.

The region under consideration may be divided into four great divisions. The coastal plain, extends from the coast to what is known as the fall line, and consists of very recent geologic formations, principally sands and gravels of Cretaceous, Tertiary and Post-Tertiary deposits. This fall line is the eastern outcrop of the old Archæn crystalline rocks of the second or Piedmont division, which extends to the summits of the Blue Ridge, and it also marks the last considerable fall on the rivers that cross it. It passes through Columbus, Macon, Milledgeville and Augusta, Ga., Columbia, S. C., Rocky Mount and Weldon, N. C., then through Richmond and Fredericksburg, Va., crossing the Potomac at Great Falls. It thence extends further northeastward and is finally lost at the mouth of the Hudson river. In the northern portion this fall line determines the limit of tide waters, but in the Southern States as it recedes from the coast it is often beyond the limit of navigation. The third division of this region is the greater Appalachian valley, extending from the Blue Ridge to the crest of the Allegheny front, and the fourth division is the Allegheny plateau, gradually sloping downward and westward from this latter boundary line. The greater Appalachian valley is a depressed zone traversed by a number of parallel ridges, and it is composed of a variety of different kinds of rocks, as con- glomerates, sandstones and limestones, the beds of which are tilted at various angles. In the Allegheny front and to the westward the strata are seen to be nearly parallel.

The Piedmont section is the oldest of the four divisions above noted, the rocks dating from Archæan times. The Blue Ridge, the western boundary of this section, is the coast line of an old continent, but of a continent facing westward and towards an inland sea. The greater Appalachian valley would, therefore, represent the shore deposits of such a sea, and one would naturally expect to find rocks diversified in color and composition along such a strip. Further to the westward or out into the sea should be and are found rocks of a more homogeneous character.

In establishing the gauging stations during 1894 and 1895 it has been the endeavor to distribute them as much as possible in these different types of areas. An important consideration has been that of the economic value of such stations. Wherevèr there has been a water-power privilege developed, and especially when there is one undeveloped on the larger rivers a gauging station has been established as near such a site as possible. In the accurate determination of the value of a water power at a certain point two things should be known: first, the fall at that place, which can be measured once and for all; and second, the variation in the discharge of the river to determine which a long series of observations are necessary.

It has been too often the practice to compute the amount of water finding its way into the rivers, by assuming a certain percentage of the rain falling on the area as drained by the river at that point. Several important factors enter into the problem of run-off, beside the rate of precipitation, these being the slope of the basin, the temperature, wind movement and the conditions 
of soil. Thus two adjoining basins, receiving the same amount of rain, but differing, in slope or in the nature of their soils, or both, will also differ more or less in their run-off. An examination of the Georgia streams has shown that highly deceptive results would be had if for two neighboring basins a certain percentage of rain were taken as giving the run-off.

A limiting factor in the location of gauging stations is the cost and accessibility of such stations. Nearly all of the United States Geological Survey gauging stations in the eastern United States are at railroad or highway bridges. Much of the field work of 1895 has consisted in inspections of such crossings. Where a suitable locality filling the engineering requirements was found, measurments of the discharge were made and there was established a gauge rod on. which the height of the river could be read daily by a man employed for the purpose and who usually resided near the bridge.

To obtain the best results the river at a measuring station should have a regular and smooth bottom, the water should have a velocity that can be measured by current meters and the channel should be straight for some distance above and below.

It seems as though bridges had been erected at points in order that gaugings could not be made from them. Either the bridge extended diagonally across the river or it was over a pool of water with little current, as in the case of the ponding of a river by a dam, or the section of the river under the bridge was rocky and filled with obstructions.

A general reconnoissance was made in July, 1895, through Virginia and West Virginia, for the purpose of inspecting the head waters of the Shenandoah, James and New rivers. As a result two stations were established at Port Republic, Virginia, one on the South Branch and the other on the
North Branch of the South Fork of the Shenandoah. These stations in connection with the one at Millville, Virginia, furnish data for the satisfactory study of this stream. On the James River stations were established on the North Fork near its mouth and on the main river at Buchanan; twenty miles above the mouth of this fork. The sum of the discharges at these two points will give the discharge of the James at Balcony Falls, the point where it breaks through the Blue Ridge and where there is a fine undeveloped water-power privilege. Passing over the divide to the head waters of the New, a tributary of the Ohio River, a station was established at Alderson, West Virginia, on the picturesque Greenbrier River, and one on the New at Fayette, West Virginia. This latter river is a torrential stream, in places widening to 2,000 feet, as at Hinton, but lower down on its course, as the surrounding mountains close in, contracting to 200 or 300 feet in width. In such places the river even in low water tumbles and foams over its rocky bottom.

By the examination of a contour map of the Appalachian region, it will be seen that the rivers draining the Appalachian valley in the northern portion, as the Susquehanna, Potomac, James and Roanoke, have a general eastward course, the divide between the Atlantic coast streams and the tributaries of the Mississippi being along the Allegheny front. Passing into North Carolina, the divide bends southeastward to the summits of the Blue Ridge. Here the Appalachian valley drainage is to the westward. After a thorough inspection of the French Broad a station was established at Asheville, North Carolina. This river is not a typical mountain stream, the valley above Asheville is comparatively broad and has little fall. The rivers to the south, as the Tuckaseegee and Little Tennessee, are more nearly typical mountain torrents, 
but owing to their inaccessibility it was not deemed advisable to establish stations on them during 1895.

The rivers of North Carolina flowing eastward and above the fall line have many large undeveloped water-power privileges. The Yadkin River at the Narrows, about 35 miles below Salisbury, is perhaps the finest water power in the State. The river just above the canyon is 1,000 feet wide, but as it enters the gorge it suddenly contracts to a width of 75 feet, and in some places even to 30 feet. In two miles the river falls 60 feet and in four miles about 110 feet. The nearest accessible point to the Narrows where a gauging station would be established was at the Southern Railroad crossing near Salisbury. The discharge as measured here last September was 1,450 second feet or a discharge of 0.43 cubic feet per second per square mile of area drained. The past season has been one of extreme low water, and this result is large compared to the run-off of more northern rivers. In fact, all of these sand-hill streams of the Southern States have a large low-water flow. The sandy soils of their basins acting as sponges absorb the spring rains and let the water off gradually in the summer time. A station was established in $\mathbf{1 8 9 5}$ on the basin of the Catawba at Fort Mill, South Carolina, also one on the Cape Fear at Fayetteville, North Carolina, and two at Clarksville, Virginia, one on the Dan and the other on the Staunton.

A partial inspection of Georgia has been made and two stations established in the State on the two most important rivers, the Chattahoochee and the Ocmulgee. The former stream is peculiar in having a very bigh summer flow. The gauging on October 15, 1895, near Atlanta gave a discharge of 0.69 cubic feet per second per square mile of area drained. A comparison of this run-off with the minimum flow of some other rivers is as follows:

\begin{tabular}{|c|c|c|}
\hline & $\begin{array}{l}\text { Drainage Area } \\
\text { in } \\
\text { Square Miles. }\end{array}$ & $\begin{array}{l}\text { Second Feet } \\
\text { per } \\
\text { Square Mile. }\end{array}$ \\
\hline Sudbury, Mas̀s., ,................. & ..... & 0.04 \\
\hline Pequannock, N. J.,.............. & $\ldots$. & 0.13 \\
\hline Ramapo, N. J., ................. & 160 & 0.14 \\
\hline Paulinskill, N. J.,.............. & 126 & 0.13 \\
\hline Neshaming,.................... & 139 & 0.01 \\
\hline Merrimac, Mass., ................ & $\ldots .4,600$ & 0.31 \\
\hline Connecticut, Conn., .............. & $\ldots . .10,234$ & 0.31 \\
\hline Potomac, Va., ,................... & $\ldots .9,654$ & 0.12 \\
\hline Shenandoah, Va.,.................. & $\ldots . .2,995$ & 0.30 \\
\hline Yadkin, N. C.,..................... & $\ldots . .3,399$ & 0.43 \\
\hline Catawba, S. C., .................... & $\ldots . .2,987$ & 0.45 \\
\hline Ocmulgee, Ga., .................. & $\ldots .2,250$ & 0.34 \\
\hline Oconee, Ga., ..................... & $\ldots . .2,973$ & 0.36 \\
\hline Chattahoochee, Ga., .............. & .... 1,600 & 0.69 \\
\hline
\end{tabular}

\section{AN ASTRONOMICAL CIPHER CODE.}

In the last number of the publications of the Astronomical Society of the Pacific, Prof. Holden prints a suggested improvement upon the Science Observer Cipher Code, devised by Messrs. Ritchie and Chandler, that has been in use by astronomers for the transmission of telegraphic announcement of astronomical discoveries during the past twelve years.

It will be remembered that this very important matter of prompt transmission of astronomical intelligence was effected through the Smithsonian Institution from 1873 to 1883 , and in the latter year arrangements were concluded by which the service was transferred to the observatory of Harvard College, the observatory thus becoming the central station for astronomical announcements in this country. A most useful code for the accurate and economical transmission of telegrams had been devised by Ritchie and Chandler, and was subsequently improved upon from time to time, and finally issued in 1888 in the shape of the Science Observer Code Book, a quarto of some 235 pages. The bulk of this is taken up by a number code covering two hundred pages and containing forty thousand words in all. The principle 